\title{
Kolektif Psikolojik Sahiplik Bağlamında İstanbul'da Yerleşik Orta Yaş ve Üzeri Ailelerin Suriyeli Göçmenlere Yönelik Algılları
}

\section{The Perceptions of the Middle and Over Aged Local Couples of Istanbul towards Syrians in the Context of Collective Psychological Ownership}

\author{
Yakup Azak ${ }^{1}$ (])
}

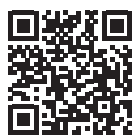

${ }^{1}$ Arş. Gör., İstanbul Üniversitesi, Fen Edebiyat Fakültesi, Psikoloji Bölümü, Fatih, İstanbul, Türkiye

ORCID: Y.A. 0000-0002-2720-7744

Sorumlu yazar/Corresponding author: Yakup Azak,

İstanbul Üniversitesi, Fen Edebiyat Fakültesi, Psikoloji Bölümü, İstanbul, Türkiye

E-posta/E-mail: yakupazak@nku.edu.tr

Başvuru/Submitted: 28.12.2020 Revizyon Talebi/Revision Requested: 19.03.2021

Son Revizyon/Last Revision Received: 02.04.2021

Kabul/Accepted: 27.04.2021

Online Yayın/Published Online: 15.12.2021

Citation/Atıf: Azak, Y. (2021). Kolektif psikolojik sahiplik bağlamında İstanbul'da yerleşik orta yaş ve üzeri ailelerin Suriyeli göçmenlere yönelik algıları. Psikoloji Çalışmaları - Studies in Psychology, 41(3), 927-957.

https://doi.org/10.26650/SP2020-848248

ÖZ

İç savaşla yerinden edilen Suriye halkının bir bölümünün Türkiye'ye göçü sonrası Suriyeliler ile yerel halk arasında gündelik hayattaki etkileşimler gruplararası gerilimleri de beraberinde getirmiştir. Bu çalışma, yerel halk ile Suriyeliler arasında gruplar arası gerilimlerin nasıl şekillendiği, kolektif sahiplik sınırlarının nerelerde çizildiği, yerel halk tarafından Suriyeli göçmenlerin nasıl konumlandırıldığı gibi sorulara gruplararası bağlamda kolektif psikolojik sahiplik (KPS) algısı üzerinden açıklama getirmektedir. Araştırmada, İstanbul'da ilçe bazlı nüfus yoğunluğuna göre ilk yirmi ilçe içinde yer alan beş farklı ilçede en az on y1l süreyle ikame eden orta yaş ve üzeri $\left(\right.$ Ort $\left._{\text {yas }}=54\right)$ on evli çift ile yapılan odak görüşmelerle elde edilen veriler, nitel analiz yöntemlerinden biri olan tematik analiz yöntemiyle analiz edilmiştir. Analizler sonucunda, şehirli yerel halkın kolektif sahiplik inşaları, Suriyelilerin oluşan KPS alanları dışında tutulması, kolektif sahipliğin kontrol kaybı endişesi ve yerel halk tarafından sunulan temenni düzeyinde çözüm önerilerinin meşrulaştırılması olmak üzere dört tema elde edilmiştir. Bulgular, Suriyelilerin kamusal alanda görünürlüğüyle birlikte yerel halkın, vatandaşlık hakları, ülkenin ekonomik kaynaklarının kullanımı gibi kolektif sahiplik alanlarını korumaya yönelik tepkiler geliştirdiğini göstermektedir. Suriyeli göçmenlere karşı yerel halkın devamlı savunduğu ve göçmenleri dışarıda tuttuğu KPS algısına sahip oldukları gözlemlenmiştir. Yerli halkın bu algıyı, KPS teorilerinin sunduğu ilk sahip, ilk yerleşen ve yatırım yapan olma ilkeleri üzerinden pekiştirebildiklerine dair bulgulara rastlanmıştır. Türkiye'deki Suriyeliler, KPS ilkelerinin gereğini yerine getirmiş olsalar bile yerli halk, başka bir ilkeyle KPS alanın kuralları yeniden belirlemekte ve Suriyeliler bu sahiplik alanı dışında kalmaya devam etmektedir. Katılımcıların, KPS alanlarını Suriyelilerden korumaya yönelik tepkilerinin arkasındaki temel motivasyonun kolektif sahipliği kaybetme endişesi olduğu görülmektedir. Katılımcıların, Türkiye'deki Suriyelilerin sorunlarına yönelik çözüm önerilerinin ise Suriyelilerin ülkelerine geri dönmeleri yönünde temennilerde ve kolektif sahipliğe davet edilmeyen çözümlerde ortaklaştığı gözlemlenmiştir.

Anahtar Kelimeler: Kolektif psikolojik sahiplik kuramı, Suriyeli göçü, tematik analiz 


\section{ABSTRACT}

After the migration of Syrians displaced during the civil war in Turkey, the interaction between immigrants and locals has led to intergroup tension. This study aims to answer the following questions through the perception of collective psychological ownership (CPO) within the intergroup context: How is tension between groups of urban locals and Syrians formed? How are the boundaries of collective ownership drawn? and How do locals position Syrian immigrants? Data, which were obtained through focus group interviews with 10 middle- or over-aged couples $\left(M_{\text {age }}=54\right)$, were analyzed using thematic analysis. The participants have been residing for at least 10 years in five out of the 20 districts in İstanbul with the highest population density of Syrians. The result provided four themes, namely, the construction of CPO by the locals, the exclusion of Syrians from CPO areas, the concern of losing control of collective ownership, and legitimization of proposals for solutions at the level of precatory discourses offered by the locals. Given the visibility of Syrians in the public sphere, the findings indicate that the locals have developed various reactions to protect several aspects of $\mathrm{CPO}$, such as citizenship rights and the use of the country's economic resources. Moreover, the study observed that locals exhibit CPO in that they constantly defend against and exclude Syrian immigrants. Several findings suggest that locals may reinforce these perceptions through the principles of CPO, that is, first owner, first settler, and being an investor. Although Syrians in Turkey comply with the CPO principles, the locals re-determine the rules over another CPO principle. As such, Syrians remain outside of the collective ownership sphere. The main reason of the participants for protecting CPO areas from Syrians is seemingly related to the concern about the loss of collective ownership. The suggestions of the participants to address the issue of Syrians in Turkey converged on a main theme of the return of Syrians to their own country.. However, inclusion of Syrians into collective ownership areas was not observed within these suggestions.

Keywords: Collective psychological ownership, Syrian refugees in Istanbul, thematic analysis

\section{EXTENDED ABSTRACT}

The interaction between Syrians and urban locals has led to intergroup tension after the migration of Syrians displaced during the civil war in Turkey. This study examines the reactions of urban locals to the visibility of Syrians in the social and cultural spheres of İstanbul from the perspective of collective psychological ownership (CPO). The concept of CPO posits that a particular group believes in their right to determine the target of ownership, how it is used, and who can use it (Verkuyten \& Martinovic, 2017). The perception of CPO provides a legitimate reason for preventing unwanted inclusion. According to scholars on $\mathrm{CPO}$, the theory proposes the three following principles for determining the means to legitimize the perception of ownership. First, the ownership principle is related to the "first to come, first to get" concept. The notion of primo occupancy represents a strong justification for territorial claims (Verkuyten \& Martinovic, 2017). Moreover, this notion is similar to an ideology that gives privilege to members of the longest established group in terms of territory (Martinovic \& Verkuyten, 2013). The second is investment principle, which suggests that investment in an object justifies ownership. For instance, the British cannot claim that they arrived in the United States or Australia as first comers. However, they can claim to have made an investment. Therefore, in contrast to Arab or Asian immigrants, they can claim to be of formative significance to the country due to their investment (Verkuyten \& Martinovic, 2017). The third is the formative principle, which denotes the formative meaning of a region due to collective identity in terms of historical rights. Apart from the 
identities of outsiders or newcomers, the priority and superiority of owners are formed in areas where owners maintain their dominant position. Several markings and signals are used to exhibit claims of ownership for the recognition of others. Control-oriented marking is a certain object or a field signified by the use of "our," which is common during interactions with out-group members. Symbolic markings, such as border controls and country flags, are sewn into a newly discovered geographic region. As such, out-group members are provided with warnings in the case of unauthorized use or entry. In identity-oriented marking, collective ownership is brought to the forefront along with social identity through social categorization. This paper presents a study on intergroup relations by discussing CPO as an important concept that lacks sufficient examination in terms of immigration in the context of intergroup conflict.

\section{Method}

The subject of the research was identified according to the boundaries of a specific region and demographic variables. The participants defined themselves as Turkish citizens and locals for at least 10 years in five out of the top 20 districts in terms of district-based Syrian population density in Istanbul. The sample consisted of 10 married couples who are middle- or late middle-aged ( $M_{\text {age }}=54$ years). The study presents the results of the thematic analysis of data obtained from focus group interviews lasting for 40 to $70 \mathrm{~min}$ and using a semi-structured approach. Participation in the research is voluntary.

\section{Results}

The findings of the study suggested four themes. The first is the construction of CPO. Ownership of the field, as the theory states, has been historically constructed on the grounds of pre-existence in the field and investment in the field. Moreover, identityoriented markings emerge between Syrians who need help and locals who help during the construction process. The second theme is the means of legitimation that Syrians are excluded from collective ownership. According to the locals, Syrians are unable to meet the investment condition as a beneficial partner in CPO. The third theme is concerned with the loss of control of ownership. The large masses and rapid transition of Syrian immigrants to Turkey continues to proceed on the basis that locals perceive as an uncontrolled situation. The last theme refers to solutions to alleviate Syrians' reported problems that would solely function as consolation.

\section{Discussion}

The results revealed that Syrians have become the object of specific moral disengagement (Bandura, 2002) by preserving the priority, control, and usage rights of collective partners. 
From the view of the locals, the Syrians are unable to meet several collective ownership conditions, such as effort and being useful. Holding historical rights refers to the right to the land in lieu of first occupancy (Verkuyten \& Martinovic, 2017), which locals use as an advantageous comparison in terms of labor for the country. The locals constantly defend CPO areas and exclude immigrants. Such CPO areas defend and rebuild themselves against Syrian immigrants despite the fact that the immigrants fulfill the conditions of being a part of collective ownership represented by CPO theory. As such, the immigrants remain excluded from these CPO areas. 
İç savaş nedeniyle yerinden edilen Suriyeli göçmenlerin bir bölümü de Türkiye’ye yerleşmiştir. 2021 yılı itibariyle Suriyeli sayısı 3.7 milyona ulaşmış olup (T.C. İç İşleri Bakanlığı Göç İdaresi Genel Müdürlüğü, 2021), bu sayının yüzde 98'inden fazlası büyük kentlerde Türk toplumu ile bir arada yaşamaktadır (Erdoğan ve Çorabatır, 2019). Bu bir arada olma halinde gündelik hayat pratikleriyle, kamusal alanda görünürlükleri ve şehirde varoluş şekilleriyle beraber Suriyeliler ile Türkiye Cumhuriyeti vatandaşı yerel halk ${ }^{1}$ arasında bir takım sosyal psikolojik gerilimler görünür hale gelmiştir. Bu çalışmanın amacı, gruplar arası bu gerilimleri yerel halkın 'bizim' olana yüklediği anlamlar üzerinden kuramsal bir çerçevede incelemektedir.

Biz ve onlar ayrımı üzerine sosyal psikoloji ve göç alan yazınında sosyal kimlik ve kategorizasyon teorileri üzerinden yapılan birçok çalışma olmasına rağmen, 'bizim' ve 'onların' ayrımıyla işaretlenen kolektif sahiplik algısını sistematik bir teori üzerinden anlamaya yönelik genel alan yazında çok az çalışmaya rastlanmıştır. Türkiye'de göç ve psikoloji alan yazınında ise herhangi bir çalışmaya rastlanmamıştır. Bu çalışma, "bizim" ve "onların" ayrımıyla oluşan düşüncelerin doğasını ve nedenlerini anlamayı hedeflemiş olması nedeniyle göç ve sosyal psikoloji alan yazınındaki boşluğa odaklanmaya yönelik bir girişim olma özelliğine sahiptir.

Çalışmanın keşifsel önemi ise göçle beraber ortaya çıkan gruplar arası sosyal psikolojik gerilimleri kolektif psikolojik sahiplik (KPS) kuramı (Verkuyten ve Martinovic, 2017) üzerinden incelemiş olmasıdır. Türkiye'de daha çok örgütsel psikoloji alan yazınıyla ilişkili olarak psikolojik sahiplik algısı ile örgütsel davranış arasındaki ilişkiyi anlamaya yönelik çalışmalar (örn., Ötken, 2015; Uçar, 2020) bulunmakta olup, kolektif seviyede psikolojik sahiplik kapsamında herhangi bir çalışmaya rastlanmamıştır.

Bu doğrultuda bu çalışmanın amacı, Türkiye'de yerel halkın Suriyelilerle arasındaki gruplar arası sosyal psikolojik gerilimlere, gruplar arası çatışma alan yazınına yeni dahil edilmeye başlanan KPS kuramı (Verkuyten ve Martinovic, 2017) üzerinden açıklamalar getirmektir. Türkiye'de yerel halk ile Suriyeliler arasında gruplar arası ilişkilerin nasıl şekillendiğine, kolektif sahipliğin sınırlarının nerelerde çizildiğine, bu kolektif sahiplik algısı içinde Suriyeli göçmenlerin nasıl konumlandırıldığına yönelik sorulara KPS kuramı üzerinden cevaplar aranmıştır.

1 Çalışmada "yerel halk" ifadesinin, yerli halk, ev sahibi topluluk (hosts ya da the locals) anlamlarını da içerecek şekilde kullanımına devam edilmiştir. 


\section{Bireyselden Kolektif Düzeye Psikolojik Sahiplik Kuramı}

Psikolojik sahiplik algısı, mülkiyet sahibi ile nesne ve diğer insanlar arasındaki ilişkilere odaklanmaktadır. Freidman (2008), mülkiyet sahibinin kim olduğunun bilinmesinin, sosyal davranışların meşrulaştırılmasında önemli bir role sahip olduğunu ve bir eşyaya, bir mekana sahip olmanın, bunlara sahip olmayan diğer kişilerle nasıl bir ilişki kurulabileceğine yönelik kararların şekillenmesinde etkili olduğunu öne sürmektedir (2008, s.290). Türkiye alan yazınında psikolojik sahiplik olgusu, sınırlı sayıda ve ağırlıklı olarak örgütsel bağlamda ele alınmış ve bu olgunun örgütsel iş tatmini, yetkinlik tatmini gibi değişkenlerle ilişkili olduğu görülmüştür (Ötken, 2015; Temizkan, 2019; Uçar, 2020; Yeşil, Bancar ve Budak, 2016). Tüketim davranışı eğilimleri üzerine yapılan çalışmalarda ürüne yönelik psikolojik sahiplik algısı ile ürünü satın alma eğilimi ve ürün hakkında diğer insanlarla bilgi paylaşım düzeyleri arasındaki ilişkiler incelenmiştir (örn., Alkaya ve Korkmaz, 2018). Bu çalışma, bireysel düzey yerine kolektif düzeyde psikoloji sahiplik algısına odaklanarak ve gruplar arası ilişkiler bağlamında meseleyi ele alarak özgün bir çerçeve sunmaktadır.

Kolektif psikolojik sahiplik, belirli bir sosyal kimlik bağlamında kendilerini "biz" olarak algılayan bireylerin "bizim” olanı kolektif bir hassasiyet içinde algılamasıdır. Bireyler, çeşitli başlıklar altında eşya veya mekanın bir grubun adına kullanım, düzenleme ve kontrol hakkının müşterek olarak kendilerinde olduğu inancına sahiptirler (Verkuyten ve Martinovic, 2017). Kolektif sahiplenme süreci sosyal psikoloji alan yazını içinde benlik kategorilendirme teorisine göre incelenebilir. Kişi, benlik kategorilendirmesine giderek grup kimliğini ve iç grupla ilgili normları, değerleri, kalıp yargıları ve davranışları benimser. Daha sonra "biz ve diğerleri” arasındaki karşılaştırmalarla ve aidiyet kurulan grubun bir olaya ya da başka bir gruba yönelik aldığı konumlarla biz olma hali somutlaşır (Turner, Hogg, Oakes, Reicher ve Wetherell, 1987). Biz olgusu, bizim olanın belirlenmesinde etkilidir. Benlik, biz bağlamında ele alındığında "biz" ile "bizim" olan arasındaki ilişki görünür olmaya başlamaktadır. İnsanlar, somut veya soyut malvarlıklar1 ve kaynakları "bizim" olan şeklinde işaretlemesiyle o şeyler üzerinde kontrol hakkının meşrulaştırılmasının yolunu açmaktadır. Bizim olanın işaretlenmesi sürecinde bu sahipliğe kimlerin dahil edilip kimlerin edilmediği de meşrulaştırılmaktadır. Verkuyten ve Martinovic'e (2017) göre grup özdeşimi KPS hassasiyeti oluşturmayabilir fakat tersi durum yani KPS algısı seviyesinde artış grup özdeşiminin artmasına yol açmaktadır. KPS algısı bir grup insan arasında ya da yerel bir bölgede komşuluk, mahalleli ve hem- 
şerilik ile işaretlenen grup aidiyetleri ve özdeşimlerinde kendini gösterebileceği gibi daha makro düzeyde ülke vatandaşlığı, yurttaşlık ile de gelişebilme imkanına sahiptir. Avrupa Birliğiyle olan üyeliğini sonlandıran Britanya’nın üyelik süreci makro düzeyde KPS'e örnek gösterilebilir. Britanya kamuoyunda, krallıkta kimin yaşayabileceği veya yaşayamayacağına yönelik karar vermede Avrupa Birliğinin etkisinin olması yoğun tartışmalara yol açmıştır. Britanya'da yerel halk nezdinde bu durum, ülkeleri üzerinde artık söz sahibi olamama düşüncelerini beslemiştir. Son dönem uluslararası politikaların belirlendiği küreselden mahalli düzeye kadar gruplar arası ilişkilerde sahibin kim olduğuna ve sahip olunanla neler yapılabileceğine dair alg1, sosyal psikoloji çalışmalarında önemli bir olgu haline gelmiştir (Verkuyten, 2018). Türkiye'de Suriye göçü ile birlikte, Britanya'da olduğu gibi yerel halkın tepkilerinin içeriğinde KPS algısına rastlanabileceğini gösteren bazı göstergeler mevcuttur. Örneğin, İstanbul Politik Araştırmalar Enstitüsü (Şar ve Kuru, 2020) araştırma raporuna göre Türkiye'de yerel halk, Suriyelileri ekonomik tehdit olarak görmekte, istihdam konusunda rakip olarak işaretlemekte ve ülke için güvenlik tehdidi olarak algılamaktadır. Avrupa Siyasal ve Sosyal Araştırmalar Enstitüsü (2017) raporu ise Suriyelilere vatandaşlık hakkı verilerek sosyal hizmetlerden yararlanabilecek olmaları halinde yerel halkın olumsuz tepkilere sahip olacağını göstermektedir.

KPS olgusu, herkesin kullanımına açık, kamusal alan olgusundan farklılık içermektedir. Örneğin kamusal alan olarak parklarda banka oturma hakkı, o banka sahip olmaktan dolayı değil, kullanıcı olma hakkından gelmektedir. Fakat sahip ile kullanıcı olma kavramlarının birbirinden keskin çizgilerle ayrımı görece zorlaşabilmektedir. KPS, kamusal alan olgusundan farklı olarak sahipliğin performe edildiği bölgecilik (territoriality) kavramıyla ilişkilidir. Brown, Lawrence ve Robinson (2005) bölgeciliğe, sahiplik hissinin davranışsal olarak dışavurumu şeklinde tanım getirmektedir. Araştırmalarında kişinin çalışma alanını sahiplenme düzeyi ile o alan üzerinde bölgeci davranışlar sergileme eğilimi arasında olumlu yönde ilişki tespit edilmiştir. Tetlock, Kristel, Elson, Green ve Lerner (2000) ise çalışmasını ulus devlet ve etnik grup bağlamına taşıyarak yetişkinler arasında bölgecilik ve milliyetçi egemenlik savlarının KPS aracılığıyla meşrulaştırılabildiğini iddia etmiştir. Pierce, Kostova ve Dirks (2001), bölgecilik ve psikolojik sahiplik beraber düşünüldüğünde, sahiplik iddiasının koruyucu davranışları meşrulaştırdığını ve bu meşrulaştırmaların aynı zamanda, sahiplenilme sürecinde gruplar arası çatışmaların ve gerilimlerin tırmanmasına neden olabildiğini iddia etmiştir. $\mathrm{Bu}$ 
bilgiler 1şı̆̆ında, gruplar arası ilişkileri inceleme altına alırken tıpkı bireysel psikolojik sahiplik algısında olduğu gibi kolektif düzeyde sahiplenmeyi meşrulaştıran temel psikolojik ilkelerin (Verkuyten ve Martinovic, 2017) incelenmesi önemli hale gelmektedir. Bu ilkeler belli bir alana ilk gelen, ilk yerleşen olmakla başlayıp zaman içinde bu alanda gerçekleştirilen yatırımlarla sahipliğin meşrulaştırılması ve belli bir grubun tarihsel kimliği üzerinden belli bir bölge üzerinde kolektif sahipliğinin meşrulaştırılması ilkesidir.

İlk Sahip, İlk Yerleşen Olma İlkesinden Yatırım İlkesine. Çocukluk ve yetişkinlik dönemlerinde bireyler, eşya üzerinde kullanım ve kontrol hakkına sahip olmalarını, o eşyanın ilk sahibi olmaları gerekçesi üzerinden meşrulaştırmaktadırlar (Friedman, 2008). Okul öncesi dönemdeki çocuklarla deneysel çalışmalar, mülkü ilk elde tutan olmanın, kimin o mülkün sahibi olduğuna dair karar verme süreçlerinde sezgisel olarak önemli bir yere sahip olduğunu göstermiştir (Friedman ve Neary, 2008). Bir yere ilk giden olmak birey ya da grup algısı düzeyinde o yerin sahibi olma iddiasının meşrulaşt1rılmasında önemli bir role sahiptir (Verkuyten, Sierksma ve Thijs, 2014). 9-12 yaş arası çocuk katılımcılarla yapılan deneysel çalışmada, coğrafi alana ilk gelen olmanın, o bölge üzerinde psikolojik sahiplik algısının meşrulaştırılmasında etkili olduğunu göstermiştir. Çalışmanın ikinci bölümünde katılımcı çocukların, alanda emek harcayan ile alana ilk gelen kişiler arasında alanın sahibinin kim olduğuna dair karar vermede, alana yatırım yapan lehine karar vererek çözüm buldukları tespit edilmiştir (Verkuyten ve ark., 2015). Yatırım ilkesi, eşya üzerinde emek göstermenin sahipliğin meşrulaştırılmasında etkili olması durumudur. Çalışmalar, katılımcıların sahiplik atıflarını mekana ilk gelenlerden o mekanda emek gösterene doğru değiştirme eğiliminde olduklarını göstermektedir (Levene, Starmans ve Friedman, 2015).

Biçimlendirici Kimliğe Sahip Olma İlkesi. Grubun sahip olduğu tarihsel kimlik, yerin/coğrafyanın üzerinde kolektif bir sahiplik iddiasında bulunmada etkili olabilmektedir (Verkuyten ve Martinovic, 2017). Amerika'daki İngiliz asıllılar Amerika’ya ilk gelenler olduklarını iddia edemeyebilirler ama İngiliz kimliği üzerinden biçimsel olarak sahip oldukları tarihsel kimlik argümanlarıyla kendilerinden sonra gelenlere kıyasla önemli oldukları iddiasında bulunabilirler. Benzer bir şekilde, birçok Yahudi, Filistin'e sonradan gelmiş olduklarını kabul etmektedir, fakat bu duruma rağmen Filistin'de dini doktrinler ile Yahudi kimliği arasında kurdukları ilişki KPS algısına neden olabilmektedir (Martinovic ve Verkuyten, 2013). KPS üzerine bir diğer önemli nokta ise sahiplik 
dışında kalana kimlerin sahip olduğunun belli edilmesidir. İşaretlemeler iki farklı temelde olabilir. Kontrol odakl işaretleme, dış grup üyesiyle iletişimde belli bir nesnenin ya da alanın bizim olduğunun işaretlenmesidir. Sınır kontrol uygulamaları, ülke bayraklarının bir coğrafi bölge keşfedildiğinde o bölgeye dikilmesi, fiziksel ve sembolik anlamı olan işaretler, çitler ve duvarlar, muhafızlar ve nöbetçi sayılarında artışa gitmek sembolik işaretlemelere örnek gösterilebilir (Walters, 2004). Tüketim kimliklerinin inşasında da bu durum gözlemlenebilir. Güvenlikli ve kapalı konutlarda mekandaki güvenlik çal1şanları ve ekipmanları, kameralar, yüksek duvarlarla bu alanlarda kurulan fiziksel net sinırlar kontrol odaklı işaretlemelere somut örnekler olarak gösterilebilir (Azak ve Tekdemir, 2021). Sınırların fiziksel olarak belirlenmediği ve muğlak olduğu alanlarda da güçlü sahiplik davranışları ortaya çıkabilmektedir. Bu tür muğlak koşullarda, grup üyeleri kolektif psikolojik sahipliği tekrar vurgulama adına kontrol odaklı tepkiler gösterebilmektedir (Verkuyten ve Martinovic, 2017). Kimlik odakl işaretlemede ise KPS algıs1, sosyal kategorizasyon üzerinden sosyal kimliklerle mesafenin ön plana çıkarıldığı durumlarda gözlemlenmektedir. Bu süreçte iç grup kimliği işaretleyicileri dışarıya görünür hale getirilmekte, iç veya dış grup tepkilerine göre kimliğin içeriği yeniden tanımlanmaktadır (Verkuyten ve Martinovic, 2017). Dış grup üyelerine tepkili bireylerin iç grup özdeşim düzeyleri daha da yükselebilmektedir. Bu durumda bireyler üyesi oldukları grubun prototip davranışlarını daha fazla icra etmekte yani benlik kategorizasyonuna daha fazla eğilimli hale gelmektedir (Turner ve ark., 1987). Hollanda' da yürütülen çalışmada, ulus özdeşimi ile göçmenlere yönelik algı arasındaki ilişkide kolektif psikolojik sahipliğin aracı role sahip olduğu tespit edilmiştir (Martinovic ve Verkuyten, 2013). Bu çalışma grup özdeşimi üzerinde KPS algısının etkisi olduğunu göstermektedir. Alan yazın KPS olgusunun aynı zamanda kimliğin devamlılı̆ıını sağlayan etkisinden söz etmektedir. Bireyin geçmiş yaşamında sahip olduğu sosyal kimlik algısının şimdiki yaşamında devam edebiliyor olması, kişinin kaygı halini negatif diğer taraftan yaşamdan memnun olma durumunu ise pozitif yönde etkileyebilmektedir (Vignoles, 2011). Çalı̧̧malar bireylerin kendi alanlarında hissettikleri sahipliğin kişilere müzakere durumlarında avantaj sağladığını göstermektedir (Smeekes, Verkuyten, Çelebi, Acartürk ve Onkun, 2017). Sonuç olarak yüksek seviyede KPS algısı, insanların kendilerini tanımlamalarına, bir yere ait hissetmelerine, yaşamda bir amaca ve yöne sahip olmalarına, zaman içinde sosyal bir kimliğin sürekliliğini hissetmelerine ve dolayısıyla kendilerini sosyal psikolojik bağlamda güçlü algılamalarına yardımcı olmaktadır. Fakat bu durum, gruplar arası ilişkilerde KPS'nin nasıl görünür hale geldiği sorularını gündeme getirmektedir. 
Alan yazında bu sorulara yönelik sınırlı sayıda araştırma bulunmaktadır. Bu araştırmada, Türkiye'de yerel halkın Suriyeli göçüne dair algılarının KPS olgusu çerçevesinde ele alınması amaçlanmıştır.

\section{Suriyelilerin Türkiye Göçü}

Suriye'de başlayan iç savaş sonucu ülke nüfusunun dörtte biri ülkelerini terk etmek zorunda kalmıştır. 2011 yılında ortalama 200 kişilik bir grup halinde Türkiye’ye göç eden Suriyeli sayısı, Göç İdaresi’nin 2021 yılı verilerine göre dokuz yıl içinde yaklaşık 3.7 milyona, İstanbul'da ise yaklaşık 500 bin kişiye ulaşmıştır (T.C. İç İşleri Bakanlığı Göç İdaresi Genel Müdürlüğü, 2021). Göç İdaresi Genel Müdürlüğü ve Mülteciler Derneği'nin yayınladığı verilerle bu sayı, 2021 Kasım ayı itibariyle İstanbul'un toplam nüfusunun yaklaşık \%3.3'üne karşılık gelmektedir (Mülteciler Derneği, 2021). BM Uluslararası Göç Örgütünün Mayıs-Temmuz 2019 raporuna göre ise İstanbul'da kayıtlı ve kayıtsız yaklaşık olarak 960 bin Suriyeli yaşamaktadır (International Organization for Migration, 2019). Bu sayılar, İstanbul'un nüfusunun yaklaşık \%6'sına denk gelmektedir. Bununla birlikte nüfusa oranla en yoğun il olmasa da İstanbul, Türkiye'nin en çok Suriyeli göçmen nüfusuna sahip şehridir (Erdoğan, 2019). Suriyelilerin yüzde 97'sinden fazlası Türkiye toplumuyla birlikte büyük kentlerde yaşamaktadır (Erdoğan ve Çorabatır, 2019). Bu birliktelik hali, yerel halk için olumlu ya da olumsuz algıları da beraberinde getirmiştir.Yerel halk Suriyelilerle duygusal ve fiziki anlamda sosyal mesafeyi korumakta ve iletişim arzuları son derece sınırlı kalmaktadır. Akfırat ve Yangın (2018), yerel halkın Suriyelilerle olan kültürel etkileşim şekilleri üzerinde Suriyelilere yönelik sosyal mesafe eğilimlerinin Suriyeli göçmenlerle bütünleşme stratejilerini benimseme eğilimini olumsuz yönde, dışlama stratejisini benimseme eğilimini ise olumlu yönde yordadığını göstermiştir. On sekiz yaş üstü katılımcılarla Suriyelilere yönelik tutumların ölçümü için Sarı ve Alkar (2018) tarafından yapılan ölçek çalışmasında toplam varyansın \%53'ünü açıklayan .73 Cronbach alfa güvenirlik değerine sahip üç faktör yapılı ölçek elde edilmiştir. Faktör yapılarının (suçla ilişkili tutumlar, evlillik ilişki tutumu, gündelik yaşama dair genel tutumlar) Suriyelilerle ilgili yapılan çalışmalarla paralellik gösterdiği görülmektedir. Kirişçi ve Ferris’e (2014) göre Türkiye’ye gelen Suriyelilerin homojen bir kültürel alt yapı yerine Alevi, Türkmen, Kürt, Yezidi ve Hıristiyan gibi farklı dini ve etnik çeşitliliğe sahip olmalarından dolayı Türkiye toplumu Suriyelilere yönelik olumsuz duygu ve tutumlara sahip olmaya başlamıştır. Yerel halkın Suriyelilere yönelik sahip olduğu olumsuz duygularla beslenen önyargılar yeni kamusal politikalarla 
azalabilmektedir (Erişen, 2018) ancak yine de mevcut toplumsal faktörler söz konusu kamusal politikaların yetersiz olmasına neden olabilir. Örneğin, İçduygu'ya (2015) göre ise Türkiye'deki sosyal ve ekonomik faktörler, Türkiye toplumunun Suriyelilere yönelik sahip olduğu misafirperverlik söyleminin düşmanca ve göçmen karşıtı tutum ve duyguların oluşturduğu söylemlerle yer değiştirmesinde etkili olmuştur.

İstanbul' da yaşayan yerel halktan ailelerin ise Suriyelilerle ilgili güvenlik üzerinden tehdit algısı düzeylerinin ekonomik tehdit algısı düzeyinden daha fazla olduğu görülmektedir (Şar ve Kuru, 2020). Suriyelilere yönelik ötekileştirme eğiliminin Türkiye toplumunda genel olarak göründüğü fakat özellikle milliyetçi politik görüşe sahip insanlarda bu eğilimin daha fazla olduğuna dair bulgular söz konusudur (Erdoğan, 2018; Şar ve Kuru, 2020).

Bu çalışma, Suriye'deki iç savaş sonrası Türkiye'ye göç etmiş Suriyeliler ile şehirli yerel halk arasında gruplar arası düzeydeki ilişkilere, yerel halkın tepkisel duruşlarındaki bizim-onların ayrımına KPS kuramı üzerinden açıklama getirmeyi amaçlamaktadır. Bu amaç kapsamında, İstanbul'da ikame eden orta yaş ve üzeri yerel halktan evli çiftlerin, aynı şehirde yaşayan Suriyelilere yönelik düşüncelerinin nasıl şekillendiği, kolektif sahiplik sınırlarının neler olduğu ve bu sahiplikte Suriyeli göçmenlerin nasıl konumlandırıldığı sorularına KPS kuramı üzerinden yanıtlar aranmaktadır.

\section{YÖNTEM}

\section{Katılımcılar}

Kolektif psikolojik sahiplik algısı teorisyenleri, sahiplik algısının bir bölgedeki yaşam süresiyle, yerleşim bölgesinde geçirilen süreyle ve o coğrafyada sahip olunan sosyal ve ekonomik sermayelerle kurulan ilişkilerle şekillenebildiğini öne sürmektedir (Verkuyten ve Martinovic, 2017). Bu teorik gereksinimlerden yola çıkarak örneklemin oluşturulması için araştırmanın evreninin belli formlarda homojenliğine odaklanılmıştır (Robinson, 2014). Araştırma evreninin coğrafi homojenliği adına, İstanbul ili Suriyeli nüfusunun ilçe bazında nüfusa oranla en yoğun yaşadığı ilk 20 ilçeden birinde en az 10 yıl boyunca ikame ediyor olmalarına dikkat edilmiştir. Demografik homojenlik için örneklemin orta yaşlı ve çocuklu evli çiftlerden oluşmasına, tarihsel ve kimliksel homojenlik için ise katılımcıların ulus kimliği/Türkiye Cumhuriyeti vatandaşlığ özdeşimlerinin yüksek seviyede olmasına dikkat edilmiştir. 
Örneklem seçiminde amaçlı örnekleme yöntemi benimsenmiştir. Örneklem homojenliği için belirlenen kriterlere sahip katılımcılardan toplanan veriler analize dahil edilmiştir. Veri kaybını engellemek adına kriterlerde ortaklaşan katılımcılara ulaşmak ve görüşmeleri yapabilmek için kar topu yöntemi üzerinden üniversite öğrencilerinden gönüllülük esasına dayalı yardım talep edilmiştir. Örneklem sayısının belirlenmesinde Guest, Bunce ve Johnson'in (2006) görüşmeye dayalı nitel araştırmalarda örneklem sayısını belirleme kriterlerinden biri olan teorik doygunluk kriteri baz alınmıştır. $\mathrm{Bu}$ kapsamda, çalışmadaki ilk yedi görüşmenin verilerinin analizi sonrasında yapılan üç görüşmeden elde edilen verilerin hali hazırdaki ilgili kod ve kategorilere yerleştiği gözlemlenmiştir. Böylece elde edilen teorik doygunluk sonucu örneklem büyüklüğü 10 görüşme (20 katılımcı) olarak belirlenmiştir.

Sonuç olarak, T.C. İç İşleri Bakanlığı Göç İdaresi Genel Müdürlüğü (2021) verilerine göre İstanbul ilinde Suriyeli sığınmacıların ilçe nüfusuna oranla en yoğun olduğu ilk 20 ilçe arasında yer alan Esenyurt, Esenler, Bağcılar, Pendik, Fatih ve Üsküdar ilçelerindeen az 10 yıldır yaşıyor olan mahalle sakini 20 kişi (10 evli çift) çalışmanın örneklemini oluşturmaktadır. Yaş ortalaması 54 olan katılımcılar orta düzey gelir seviyesine sahiptir. Katılımcılar için dini değerlerin (3. katılımcı çift hariç) yaşam şekillerinin belirlenmesinde kendileri için önemli olduğu ifade edilmiştir. Katılımcılara ait diğer bilgiler Tablo 1'de sunulmuştur. 
Tablo 1. Katılımcı Ailelerin Demografik Bilgileri

\begin{tabular}{|c|c|c|c|c|c|}
\hline Katılımcılar & $\begin{array}{c}\text { Aile üyelerinin } \\
\text { meslekleri }\end{array}$ & Ĕgitimleri & Yaş & Çocuk sayısı & $\begin{array}{c}\text { İstanbul'da ikamet } \\
\text { süresi ve ilçesi }\end{array}$ \\
\hline $\begin{array}{l}\text { Erkek } 1 \\
\text { Kadın } 1\end{array}$ & $\begin{array}{l}\text { Emekli, } \\
\text { Ev hanımı }\end{array}$ & $\begin{array}{l}\text { Lise } \\
\text { Lise }\end{array}$ & $\begin{array}{l}54 \\
48\end{array}$ & 2 & 15/ Esenyurt \\
\hline $\begin{array}{l}\text { Erkek } 2 \\
\text { Kadın } 2\end{array}$ & $\begin{array}{l}\text { Avukat } \\
\text { Emekli }\end{array}$ & $\begin{array}{l}\text { Üniversite } \\
\text { Lise }\end{array}$ & $\begin{array}{l}52 \\
56\end{array}$ & 3 & 40/ Üsküdar \\
\hline $\begin{array}{l}\text { Erkek } 3 \\
\text { Kadın } 3\end{array}$ & $\begin{array}{l}\text { Ev erkeği } \\
\text { Hemşire }\end{array}$ & $\begin{array}{l}\text { Üniversite } \\
\text { Üniversite }\end{array}$ & $\begin{array}{l}51 \\
41\end{array}$ & 1 & 23/ Pendik \\
\hline $\begin{array}{l}\text { Erkek } 4 \\
\text { Kadın } 4\end{array}$ & $\begin{array}{c}\text { Esnaf } \\
\text { Ev hanımı }\end{array}$ & $\begin{array}{l}\text { Lise } \\
\text { Lise }\end{array}$ & $\begin{array}{l}49 \\
39\end{array}$ & 2 & 18/ Bağcılar \\
\hline $\begin{array}{l}\text { Erkek } 5 \\
\text { Kadın } 5\end{array}$ & $\begin{array}{l}\text { S. meslek } \\
\text { Ev hanımı }\end{array}$ & $\begin{array}{c}\text { Lise } \\
\text { Ortaokul }\end{array}$ & $\begin{array}{l}48 \\
40\end{array}$ & 3 & 22/ Bağcılar \\
\hline $\begin{array}{l}\text { Erkek } 6 \\
\text { Kadın } 6\end{array}$ & $\begin{array}{c}\text { Şoför } \\
\text { Öğretmen }\end{array}$ & $\begin{array}{c}\text { Lise } \\
\text { Üniversite }\end{array}$ & $\begin{array}{l}37 \\
32\end{array}$ & 2 & 14/ Esenler \\
\hline $\begin{array}{l}\text { Erkek } 7 \\
\text { Kadın } 7\end{array}$ & $\begin{array}{c}\text { Belediye çalışanı } \\
\text { Terzi }\end{array}$ & $\begin{array}{l}\text { Ortaokul } \\
\text { Ortaokul }\end{array}$ & $\begin{array}{l}53 \\
47\end{array}$ & 4 & 26/ Esenler \\
\hline $\begin{array}{l}\text { Erkek } 8 \\
\text { Kadın } 8\end{array}$ & $\begin{array}{c}\text { Emekli } \\
\text { Ev hanımı }\end{array}$ & $\begin{array}{l}\text { İlkokul } \\
\text { İlkokul }\end{array}$ & $\begin{array}{l}77 \\
68\end{array}$ & 4 & 27/ Fatih \\
\hline $\begin{array}{l}\text { Erkek } 9 \\
\text { Kadın } 9\end{array}$ & $\begin{array}{c}\text { Emekli } \\
\text { Ev hanımı }\end{array}$ & $\begin{array}{l}\text { İlkokul } \\
\text { İlkokul }\end{array}$ & $\begin{array}{l}80 \\
70\end{array}$ & 5 & 38/ Bağc1lar \\
\hline $\begin{array}{l}\text { Erkek } 10 \\
\text { Kadın } 10\end{array}$ & $\begin{array}{c}\text { Emekli } \\
\text { Ev hanımı }\end{array}$ & $\begin{array}{l}\text { İlkokul } \\
\text { İlkokul }\end{array}$ & $\begin{array}{l}75 \\
66\end{array}$ & 4 & 32/ Esenyurt \\
\hline
\end{tabular}

\section{Veri Toplama Araçları}

Çalışma boyunca görüşmelerde kullanılan sorular, pilot görüşmeler üzerine yapılan analizler sonucu son halini almıştır. Araştırma süresince iki adet pilot görüşme ve 11 adet görüşme olmak üzere toplamda 13 görüşme yapılmıştır. Analizler, 10 adet görüşmeyle yürütülmüştür. Görüşme sorularında, katılımcı çiftlerin sosyo-demografik geçmişleri, dini ve vatandaşlık özdeşim durumları, İstanbul'da yaşam ve varsa göç deneyimlerine dair sorularla psikolojik sahipliğin davranışsal dışavurumu olan bölgecilik eğilimlerine dair bilgiler elde edilmeye çalışılmıştır (Brown ve ark., 2005). Suriye göçü hakkındaki görüşlerine, Suriyeli göçmenlerle olan deneyimlerine, Suriyeli göçmenlerin Türkiye'de sahip oldukları sosyal haklar ve yaşantıları hakkındaki görüşlerine, göç meselesine katılımcıların yaklaşım ve çözüm önerilerine yönelik sorular yöneltilmiştir. Böylece psikolojik sahipliğin kimlik ve kontrol odaklı işaretlemelerine, ne tür kimlikler performe edildiğine (Verkuyten ve Martinovic, 2017) ilişkin bilgiler elde edilmesi amaçlanmıştır. Bununla beraber görüşme sorularına Suriyelilerin Türkiye Cumhuriyeti vatandaşı olabilmelerine dair katılımcı görüşlerinin alınabileceği sorular eklenerek tepkisel KPS algılarına yönelik veriler elde edilmesi amaçlanmıştır (bkz. Ek1). 
Katılımcıların Türkiye Cumhuriyeti özdeşim seviyelerinin yüksek olması örneklemin homojen yapısı için önemli bir kriterdi bu sebeple katılımcılara, "Kendinizi ne derece bu ülkenin bir vatandaşı olarak görüyorsunuz ve bu ülkenin vatandaşı olmak sizin için ne anlama geliyor?” şeklinde vatandaşlık algısı sorusu yöneltilmiştir. Böylece katılımcıların Türkiye Cumhuriyeti vatandaşlığına ilişkin ulus özdeşim düzeyi, Vignoles'in (2011) önerdiği paylaşılan ve geçmişe dayanan ortak bir tarihe sahiplik duyma, kendini evinde hissetme, bu ülkenin vatandaşı olmaktan gurur duyma halini işaretleyen ifadelerin yer alması kriteri üzerinden belirlenmiştir.

\section{İşlem}

Çalışmanın verileri, 2019 yılı Ocak-Mayıs zaman aralığında toplanmıştır. Veriler, yarı yapılandırılmış yaklaşımla, 40 ile 70 dakika arasında değişen sürelerde her bir çift ile aynı anda yüz yüze odak görüşmelerle elde edilmiştir. Katılımcıların görüşlerini rahat bir şekilde ifade etmelerine engel olacak dış etkenleri asgari duruma indirmek için görüşmeler, katılımcıların kendi ev ortamlarında gerçekleştirilmiştir. Görüşmelerin odak görüşme şeklinde yürütülmesinin tercih edilme sebebi katılımcıların birbirleriyle etkileşim içinde ortak bir biçimde Suriyelilere yönelik inançları, düşünceleri ve duyguları üzerinden inşa ettikleri anlamlarla ortaya çıkan verinin elde edilmesinin amaçlanmış olmasıdır.

Görüşmeler öncesinde katılımcılara kendilerinden elde edilecek verinin ne amaçla kullanılacağını, çalışma için tercih edilme nedenlerini, veri toplama gereci olarak ses kayıt işleyişini içeren bilgi-onam formu dağıtılmıştır. Görüşmelerden birinde, katılımcıların ev ortamına davet edilme konusunda birtakım engeller nedeniyle görüşmeyi araştırmacı yerine gerçekleştirmesi için çalışmamın teorik içeriği ve yöntemi konusunda bilgi alışverişinde bulunulan uzman psikolog bir meslektaştan yardım istenmiştir. Görüşmenin incelenmesi sonucunda görüşmecinin göç meselesine dair kişisel yargı ve değerlerini katılımcılara yansıttığına dair düşünceler kendisiyle paylaşılmıştır. Görüş birliğine varılıp bu görüşmeden elde edilen verinin araştırmaya dahil edilmemesi kararlaştırılmıştır. Veriler, odak grup görüşmeler esnasında katılımcılardan onaylı ses kayıtları alınarak elde edilmiştir. Ardından bu ses kayıtları katılımcıların anonim kalmaları sağlanarak yazıya dökülmüştür. Yapılan görüşmelerin yazı dökümleri ilgili katılımcılarla paylaşılarak katılımcıların görüşleriyle araştırmacının bu görüşleri sunumunun birbiriyle uyumunu arttırma yolu tercih edilmiştir. Katılımcı kontrolü olarak da adlandırılan bu yöntem ile hem araştırmanın etik boyutuna hem de verinin güvenirliliğine (iç geçerliliğine) olumlu yönde katkı sağlamaktadır (Tobin ve Begley, 2004). 


\section{Veri Analizi}

Analizler, Amerikan Psikoloji Derneği'nin (APA) niteliksel ve karma yöntemlerin yayınlanmasında belirlediği raporlama standartları (Levitt ve ark., 2018) çalışmalarında tematik analiz yöntemi için atıfta bulunduğu Braun ve Clarke'ın (2006) tematik analiz uygulama adımları temel alınarak yapılmıştır. Tematik analiz, bir veri setinde bulunan temaları belirlemek, analiz etmek, düzenlemek, açıklamak ve raporlamak için kullanılan bir yöntemdir. Analizler Maxqda 2018 programıla yapılmıştır. Tümevarımsal bir yaklaşımla analiz süreci yürütülmüştür. Kodlama sürecinden önce bütün görüşmelerden elde edilen verilerin yazı dökümleri, ilk görüşmeden başlayarak son görüşme dahil geçen sürede birikimli bir şekilde tekrar tekrar okunmuştur. Aşina olunan verinin kodlama aşamasında araştırmacının ön yargılarını asgari düzeyde tutmak için kodlama kılavuzu (Braun ve Clarke, 2006) oluşturulmuştur. Araştırma dişında yer alan bir uzman psikologdan k1lavuzdaki alt temalar ve kodlamalarla ilgili olumlu yönde emsal değerlendirmesi alınmıştır. Clarke ve Braun (2013), elde edilen temaların araştırma sorularına cevap niteliğinde olmasından ziyade araştırılan mesele hakkında bir şeyler söylemesi gerekliliğine dikkat çekmektedir. Çalışmanın temalar üzerinden meseleye dair iddialarını güçlendirmek için veri, KPS kuramının sunduğu ilk sahip, ilk yerleşen olma, yatırımc1 ve biçimlendirici kimliğe sahip olma ilkeleri ile kimlik ve kontrol odaklı işaretlemeler perspektifinden analiz edilmiştir. Bu süreçte söylenenlerin tanımlanmasının ötesinde düşüncelerin altında yatanlar, varsayımlar ve kavramlar görünür hale getirilmeye (Maguire ve Delahunt, 2017) çalışılmıştır. Oluşturulan taslak temalardan yeterince veriyle desteklenemeyenlerin diğer temalarla olan ilişkileri gözden geçirilmiştir. Nihai olarak temaların kendi içlerinde homojen diğer temalarla heterojen bir yapıda olmasına (Braun ve Clarke, 2006, s. 91) dikkat edilerek dört tema elde edilmiştir.

\section{BULGULAR}

Görüşmeler esnasında katılımcı çiftlerin birbiriyle olan etkileşimi sonucu elde edilen veriler dört tema altında toplanmıştır. Çalışmada her bir temayı en iyi temsil eden alıntılara yer verilmiştir. Bulguların sunumunda da kadın katılımcılar K1-K7, erkek katılımcılar ise E3-E10 şeklinde sadece cinsiyetleri belli olacak şekilde anonimleştirilmiştir.

\section{Tema 1: Kolektif Psikolojik Sahiplik İnşası}

İstanbul'da mahalle sakini ve Türk vatandaşı olma deneyimleri içinde katılımcıların kolektif psikolojik sahipliği nasıl inşa ettiklerine dair ifadelerin yer aldığı temadır. Alt- 
mış altı yaşındaki kadın katılımcının bu coğrafyayı, bireysel tarihi üzerinden "benim vatanımdır” atfıyla kendisinin söz sahibi olabileceği bir yere dönüştürdüğü gözlemlenmektedir. İnsanların anlatılarında ulus kimliği devamlılıklarına sahip olmaları ulus kimliği özdeşimi düzeylerinin de yüksek olduğunu göstermektedir (Smeekes ve ark., 2017). $\mathrm{Bu}$ alıntıda da geçmiş, şu an ve geleceği işaretleyen ifadeler aynı zamanda kimlik devamlılığı üzerinden yüksek ulus özdeşimi seviyesi hakkında önemli bir göstergedir.

“Yani burda doğup burda büyüdüğ̈̈n burda yaşamışsan burda ölmüşsen burda yaşlanmışsan burası benim vatanımdır derim” (K10, 66 yaş).

Bireyin mekanda doğumu, geçinmesi, yaşamını yitirmesi gibi dönemleri deneyimlemiş olması o coğrafyaya kendi tarihsel kimliği ile biçimlendirici bir etkide bulunmasının yolunu açmıştır. Yer, katılımcı ve katılımcı gibi o bölgede bireysel tarihe sahip olanların kolektif sahiplik iddiasına uygun hale gelmiştir (Verkuyten ve Martinovic, 2017). Kırk yedi yaşındaki katılımcı K7, İstanbul'daki yaşamını KPS algısının “öncelik” iddiasıyla meşrulaştırmaktadır. Bu öncelik iddiası katılımcının sahipliği elinde bulundurma mücadelesinin içinde olduğunu göstermektedir. Brown ve arkadaşlarının (2005) işaret ettiği gibi sahiplik elde edildiği zaman beraberinde mücadeleleri de getirmektedir. Sahip olunan şey, tehditlere ve tartışmalara açık haldedir. Bu durum aynı zamanda onun korunması, tekrar sahipliğin belli edilmesi davranışlarına da yol açabilmektedir.

“Önce kendim diyorum. Çünkü ben burda yaşıyorum benim burda çocuklarım var benim burda çocuklarımın geleceği olması lazım. Gerçi dinde önce kendin değildir hani önce derler dinde komşun etrafin ama biz yine de önce kendimiz diyoruz. Ne kadar öyle desen de biz önce kendimizi düşünüyoruz çok da anormal değil normal bişey bence ben bir canlı olarak burada yaşıyorum ben bir canlıysam kendimi düşünmek zorundayım hani ilk önce kendim diyorum” (K7, 47 yaş).

K7 ifadelerinin devamında sahip olduğu iki kimlik arasında gerilimin farkındadır. $\mathrm{Bu}$ gerilim, öğretilerine değer verdiği dini temelli ahlaki kimliği ile bakım veren anne kimliği arasındaki bir gerilimdir. Kendi içinde yaşadığı çelişkili durumunu kimliğine getirdiği biyolojik bir işaretlemeyle ortadan kaldırmaya çalışmaktadır. KPS'nin grubun sahip olduğu tarihi kimlik ya da bölgeye ilk yerleşen olma ilkelerinden farklı olarak, bu ifadelerde katılımcı sosyal yönü, prososyal eğilimi olan bir canlı olma halinden biyolojik benmerkezci bir canlı olma haline geçiş yapmaktadır. Diğerkam davranışlar sergilen- 
mesi durumunda bu davranışın kaynaklar oranında yapılması ve önceliğin Türkiye Cumhuriyeti vatandaşlarında olması gerektiğinin vurgulanması kararlarında KPS algısının etkili olduğunu göstermektedir. Katılımcı kaynağın kullanımı ve kontrolü üzerinde söz sahibi olduğunu işaretleyerek KPS algısını görünür hale getirmiştir.

“Türkiye'de o kadar zor durumda geçinen insanlarımız var ki onlar da dediğim gibi yani bütün ülkeler Avrupa ülkesi aslında, Türkiye'deki Suriyeli insanlara yardım etmesi lazım. Türkiye'de bizim zor çok zor durumda insanlarımız var ona rağmen yine de baklyoruz ama Avrupa ülkesin de yani bu şeylere artıkın yani el atması gerekiyor. Yardım etmeyen ülkeler çok var ilgilenmeyen ülkeler çok var” (K8, 68 yaş).

K8 Suriyelilere yardım yapılması konusunu 'bizim çok zor durumdaki insanlarımız' olarak işaretlediği sosyal grubunu dikkate alarak değerlendirmektedir. Suriyeliler ile iç grup üyesi Türkiye'deki yardıma muhtaç insanları iç grup yanlılığı ile değerlendirmesi sonucu Türkiye'de Suriyelilere yapılan yardımın Avrupa ülkeleri desteği ile yapılması gerekliliği düşüncesi oluşmuştur. Sahip olunanların nasıl kullanılacağı ve kullanıcılarının kimler olması gerektiği kimlik odaklı işaretlemelerle belirlenmiştir. Suriyeliler kullanıcı olarak değil sadece bakım gören kişiler olarak işaretlenmiştir. İnsani yardıma ihtiyaç duyanlar olarak algılanan Türkiye'deki Suriyeli göçmenler katılımcı tarafından bölgeci bir davranış eğilimiyle (Brown ve ark., 2005) kolektif psikolojik sahipliğe dahil edilmemektedir.

\section{Tema 2: Suriyelilerin Kolektif Psikolojik Sahipliğin Dışında Tutulması}

Mülk veya mekanın doğal sahibi olma halinin meşrulaştırılması sonrası katılımcıların göçmenleri bu sahipliğin dışında tutma gerekçelendirmelerinden elde edilen temadır. Katılımcıların gözünde Suriyeli göçmenlerin Türkiye'de vatandaş olabilmelerine yani kolektif sahiplik haklarına dahil olabilmelerine yönelik olumsuz değerlendirmeleri bulunmaktadır. Bu değerlendirmelerde sunulan gerekçelerin KPS'in ilk sahip, ilk yerleşen olma ve yatırım ilkelerine yönelik ihlaller üzerinden sunulduğu gözlemlenmiştir.

“Ama ben diyorum ki ülkesi için savaşmayan ülkesi için çabalamayan insan başka ülkenin insanına da faydalı olmaz diyorum yani. Çünkü kendi ülkesine faydası olmayan insanın başka ülkeye hiçbir faydası olmaz çünkü çalışmadan üretmeden mücadele vermeden kazanmadan insanlar böyle bir beklenti içinde öyle bi beklentide yok yani. Her şey vatan için vatan uğrunda ölen varsa vatan vatandır” (E1, 54). 
Göçmenin ülkeye faydası olmayan, çalışmayan, üretmeyen olarak işaretlenmesi KPS kuramı açısından yatırım ilkesi ihlali olarak yorumlanabilir. Dış grup üyesinin mülk ya da mekana sahipliğini kabul etmek için dış grup üyesinin nesne üzerinde emek göstermesi beklenmektedir. E1 bu beklentinin karşılanmayacağına dair algısını, dış grup üyesi Suriyeli göçmenin mekan üzerindeki emeği halihazırda kendine ait olan Suriye toprakları için göstermemesiyle gerekçelendirmiştir. Coğrafyada emek sahibi olma ve yere yatırımda bulunma sahiplik iddiasının o yerde meşrulaştırılması için gerekli şarttır (Verkuyten ve ark., 2015). Emek harcama ve fedakarlık ile sahiplik arasında kurulan ilişkiye ek olarak alıntıda kimlik odaklı işaretlemeler gözlemlenmektedir. Harcanan emek ve gösterilen fedakarlık, sahiplenilecek olan mekana kimlik kazandırmaktadır. E3 için Suriyeli göçmen, KPS kuramı içinde yatırım ilkesi ihlali gerekçesiyle kolektif sahipliğe dahil edilmemektedir.

"Yani mesela ben burda 50 yaşımdayım. Elli yaşıma kadar yaşadı̆̆ım hakları ben almışsam elime burda dün gelip de aynı haklara sahip olmalarını yani burda yaşamalarını istemiyorum.... Kalkıp ta işte bazı yerlerimizi sahiplenmeye çıkmalarını istemiyorum yani o beni kaygılandırıyor o da beni kaygllandırıyor" (E3, 51 yaş).

E3, yaş vurgusu yaparak mekanda geçen zaman ve sahiplik arasında kurulan ilişki ile sahiplik hakkı meşrulaştırmasına gitmektedir. Bu hakkın elde edilmesi için mekanda harcanan emek dışında bir de o mekanda geçirilen zaman miktarı da sahiplik algısı için önemli bir belirleyici haline gelmiştir. Katılımcı, kendisinin mekana sahipliğini, 50 yıl süren yatırım ve emeğini ifade ediyor olması KPS kuramı açısından kimliğin sabitliğine dair işaretleme olarak ele alınabilir. Bireyin geçmiş yaşamında sahip olduğu ile şimdiki sosyal kimlik inşası arasındaki bağlantısızlık kişinin kaygı düzeyini arttırmakta ve yaşam memnuniyetini olumsuz etkileyebilmektedir. Suriyeli göçmenlerin, kamusal alanda E3 ile aynı haklara sahip bir kullanıcı olabilme durumu katılımcının Vignoles'in (2011) değindiği gibi müzakere durumlarındaki avantajını olumsuz yönde etkileyebilmektedir.

"Evet tabi yardım edilsin edilmesin değil. Ama bi hastanede mutlaka siranın önce bizde olması gerek. Burda yasıyorum, Türkçe konuşuyorum. Bu memleket için emek harcadım bi bakıyosun senin verdiğin vergilerle onlar var her yerde” (E9, 80 yaş).

Seksen yaşında erkek katılımcı E9, Suriyeli göçmenlere yardım edilmesine yönelik düşünceleri ile Suriyeli göçmenlerin kamusal alanda görünür olmasına yönelik düşünceleri arasında farklılıklar gözlemlenmektedir. Göçmene yardım edilebilir fakat 
onunla mekan paylaşımını eşit kullanım hakkı üzerinden müzakereye açmak sorun teşkil etmektedir. KPS dışında tutulan Suriyeli göçmen yatırım ve kimlik işaretleyicileri olan Türkçe dil kullanımı üzerinden biçimlendirici ilkelerini ihlal etmektedir.

Başka bir katılımc1 K4 (39 yaş), “ikinci bir şekilde aynı haklardan gene ikinci şekilde yararlanabilecek bi haklara sahip olmasını düşünmüyorum” ifadelerinde, Suriyeli göçmenlerin Türkiye Cumhuriyeti vatandaşlığının sunduğu kolektif sahipliğin kullanıcıları olmalarını istememiştir. Katılımcının eşi E4 ise “onların bir vatanları varken ikinci vatana sahip çıkmalarını hele benim ülkeme sahip çıkmalarını aynı vatandaşlık haklarına sahip olmalarını istemiyorum” ifadelerinde vatandaşl1k verilmesini kimlik odaklı işaretlemeyle vatana sahip çıkma bağlamında ele almıştır. Her iki katılımcı da Suriyeli göçmenleri KPS alanının dışında tutmuştur.

Beşinci aileden, 40 yaşında katılımeı K5, KPS alanına dahil edilme şartı olarak Suriyelilerce yatırım ilkesinin yerine getirilmesi gerekliliğini vurgulamıştır: "Çorbada bi tuzu bulunmadan ülkenin gelişmesinde savunmasında bulunmadan vatandaş olmak o kadar kolay olmasa gerek”. Fakat katılımcı konuşmasının devamında “onun kültüründen olması lazım onun kültürünü onu şeyini benimsemiş olması lazım onu bi yerde onun hamurundan olması lazım ki dil kültür farklılı̆̆ hadi din birlikteliğimiz var ama kültür farklılı $\breve{g} l$ ” ifadeleriyle yatırım ilkesinin karşılanmasının yeterli olmayacağını belirtmiştir. İfadelerin devamında Suriyeli göçmenlerin KPS için biçimlendirici özelliklerin yani tarihsel kimliğin hali hazırda KPS için uygun olması gerekliliğini vurgulamıştır.

Tüm bu ifadelerde kimlik odaklı işaretlemelerle sosyal kategorizasyona gidilerek Suriyeli göçmenlerle sosyal mesafeler belirlenmiştir. Bu süreçte KPS'nin iç grup üyesinin dış grup üyeleri konumlandırmasına göre şekillendiği görülmektedir. Suriyeli göçmen "farklı hamurdan” olan şeklinde KPS kuramı bağlamında tarihsel ve biçimlendirici bir kimlik üzerinden kolektif sahipliğin dışında tutulmuştur.

\section{Tema 3: Kolektif Sahipliğin Kontrol Kaybı Endişesi}

Mekanın ya da mülkün kullanıcılarının kim olduğunun muğlaklaştığı, kontrol edilebilirliğin ve kolektif sahiplik algısının belirsizleştiği durumlara dair ifadelerden elde edilen temadir.

Kadın katılımcı K10, "ama işte aldığında da Türkiyeye girdiklerinde de sonra işte diyorsun ki ya devletimiz bunları buraya niye sokmuşlar” ifadelerinde göçmenin 'içeri- 
ye sokulmasını' kolektif sahiplik duyulan alana müdahale olarak değerlendirmiştir. Katılımcıya göre bu müdahale ile mülk ve mekan üzerinde dışarıdan gelenin sahiplik iddiasında bulunması kolaylaşmıştır. Katılımcı sözlerine “... sanki kendi ülkeleriymiş gibi o kadar rahatlar ki seni eziyorlar resmen sen kendin sanki burda sen yabancisin hani bir kardeş gibi yaşayacă̆ı yerde adamlar... " ifadeleriyle devam etmiştir. Bu ifadelerde Suriyeli göçmenin kendini 'rahat hissetmesi' ve bu rahatlığın kamusal alanda görünürlüğü sonucunda katılımcı 'yabancı' olma atfıyla kendi kimliğini yeniden tanımlamıştır. Biz ve onlar ayrımının muğlaklaştığı durumlarda iç grup üyelerinden kolektif sahipliği tekrar vurgulama adına KPS kuramının işaret ettiği gibi kontrol odaklı tepkiler oluşmaktadır (Vekuyten ve Martinovic, 2017). Suriyelinin rahat olmasına karşı katılımcının kendini eziliyor hissetmesi gibi memnuniyetsizlikler, KPS kuramına göre göç öncesinde katılımcının sahip olduğu sosyal kimlik algısının göç sonrasında devam edemediği endişesine yol açmaktadır.

“Ülke içine salınarak halkımız arasında da işsizlik baş gösterdi bu konuda iş imkânları azaldı çünkü bunlar ucuz iş gücü olarak işveren de bunları tercih etmekte” (E6, 37 yaş)

Suriyelilere yönelik ekonomik tehdit algısı, işsizliğin ve iş rekabetinin artışına dair bulgularla açıklanması birçok çalışmanın ortak noktasıdır (Erdoğan, 2017; Erdoğan ve Çorabatır, 2019; Şar ve Kuru, 2020). Alıntı, bu bulgulara farklı bir yaklaşım getirilmesine olanak sağlamaktadır. 'Ülke içine salınarak' ifadesi, kolektif sahiplik algısının temel özelliklerinden biri olan sahip olunan şeyleri kontrol altında tutabilme imkanının tehlike altında olduğu algısına işaret etmektedir. E6 ülkedeki iş imkanlarının kime ve hangi kullanıcılara yönelik olduğunun muğlaklığına dair endişelere sahiptir. İş rekabetinde yaşanan endişe sahip olunan iş kaynaklarının kontrolüne dair KPS algısının muğlaklaşması halinde yaşanan endişeyle iç içedir (Verkuyten ve Martinovic, 2017).

“Çünkü neden yanlış politika burada ülkemize bi sürü mülteci kontrolsüz bi şekilde alındı ve bunlar ülke içine salınd r rahat bi yaşam ikametgâh barınma gezme tozma her türlü faaliyetleri söz konusu böyle olunca toplumda kargaşa başladı çünkü bunları bă̆layan hiçbir şey yok. Bu yüzden toplumsal hareketler de oldu bi takım olaylar yaşandı gerek Gaziantep 'te gerek Konya Beyşehir'de Suriyelilerle ilgili bi toplumsal olaylar yaşand y yani buna benzer" (K2, 56 yaş)

K2 tarafindan Türkiye toplumunun diş grup üyesi olarak Suriyelilerle arasındaki sosyal kimlik sınırlarının yanlış politikalarla muğlaklaşmasına yönelik memnuniyetsiz- 
likleri dile getirilmiştir. 2020 tarihli araştırma raporundaki verilere göre Türkiye toplumu içinden katılımcılar, Suriyelilere yönelik toplu yürüyüş ve toplu imza gibi kolektif eylemlere sırasıyla yüzde 34.3 ve yüzde 42.6 oranında katılma eğilimindedir (Şar ve Kuru, 2020). Bu bulgularla ilişkili olarak bu alıntıda da katılımcının Suriyelilere karşı kolektif eylemleri meşrulaştırma şekilleri görülmektedir. K2, KPS'nin kontrol odaklı davranışsal tepkilerini ‘toplumsal hareketler' şeklinde ortaya çıkmasını muğlak koşullarda meşrulaştırabilmektedir. Kolektif psikolojik sahipliği olan iç grup üyeleri kendi sosyal kimlikleriyle Suriyeli göçmenlerle olan sosyal mesafelerini daha somut pratiklerle görünür hale getirmektedir. Bu yeni kimlik kurulumları kontrol sahibi olunanlar üzerinde kontrolün kaybı endişesi sonucunda gerçekleşmektedir.

Görüşmeler esnasında katılımcıların Suriyeliler üzerinden etkileşimlerinde dolaylı yoldan elde edilmiş fikirlerin de etkili olduğu gözlemlenmektedir. E6, üçüncü şahıstan elde ettiği Suriyelilerin Türkiye toplumu hakkında "her şeylerini vermeye hazırlar yani neredeyse istesek karlarını da verecekler" şeklindeki varsayımsal ifadeleri dile getirmiştir. Katılımcının eşi de K6 “o kadar terbiyesizler” şeklinde tepki göstermiştir. E6 ise "bunlara bir güzel dayak atıyorlar ellerine sağlık o kadar pislikler ama çoğu böyle" ifadeleriyle sözlerine devam etmiştir. Bu diyalogda Suriyelilerin her an her şeye sahip olabileceklerine hatta bunun da sınırının olmadığına yönelik oluşan algı katılımcılar için büyük bir endişe kaynağıdır ve karşılığında şiddete dayalı tepki meşru haldedir. Bu alıntı, yeni potansiyel sahiplerin ve kullanıcıların varlığı ile sahiplik hissinin saldırgan bir şekilde dışavurumunun meşrulaştırılışı ve ‘bölgecilik' anlayışının oluştuğu görülmektedir. Bu durum, Brown ve arkadaşlarının (2005) öne sürdüğü bölgecilik kuramı ile açıklanabilir hale gelmektedir. "Bize" ait olanın alanı ihlal edildiği durumda verilecek müeyyideler ve kınamalar meşrulaşmaktadır (Zebian ve Rochat, 2012).

\section{Tema 4: Temenni Düzeyinde Çözüm Önerilerinin Meşrulaştırılması}

Katılımcıların Suriye göçüne yönelik meselelere çözüm önerilerinin temenni düzeyinde olduğu gözlemlenmiştir. Katılımcılar tarafından Suriyelilerin kolektif sahiplik d1şında tutulması yönünde fikirlerin ortaklaştı̆̆ı çözüm önerileri sunulmaktadır. Katılımcılar, KPS kaybına dair endişe üzerinden tehdit olarak görünen Suriyelilere yönelik yeni davranış düzenlemeleri fikrine veya tutum değişimlerine sahip olabilmektedir. E1, "savaşları bitene kadar dursunlar sonra gitsinler kalıcı olmasını istemiyorum" şeklindeki ifadelerinde, alanda kimin ne kadar kalabileceğine dair bölgeyi koruma ve kontrol (Brown ve ark., 2005) talebinin ortaya çıktığı KPS eğilimi görülmektedir. Kat1- 
lımcının, 48 yaşındaki eşi K1 ise "herkes kendi ülkesinde mutlu olur inşallah tabi onlar da istemez yuvasını dağıtıp yeni yere gelmek perişanlar ama herkes kendi yuvasında mutlu olur" şeklinde ifadeleriyle "mutlu olma" hakkına ancak dış grup üyelerinin farklı bir kolektif sahiplik mekanı sınırları içinde yani "kendi yuvasında" yaşaması şartıyla sahip olabileceği ifade edilmiştir. Yuvasızlık ve yeni bir yerde yaşamak, zor durumda kalmakla ilişkilendirilmiştir.

“İnşallah savaş biter suriyeliler kendi ülkelerine döner orda çalışır askerliklerini de kendi ülklerinde yaparlar. Hem vergilerini verirler hem dinlerini yaşarlar hem de vatanlarına bayraklarına sahip çıkarlar. Kimseyi allah vatansız bırakmasın bayraksız blrakmasın. Zor bir hadise suriyelilerin yerinde olmak istemezdim. Inşallah suriyelilerde aynı benim gibi düşünürler bir an önce kendi ülkelerinde rahatça yaşama hakkına sahip olurlar” (K 10, 66 yaş)

K10 ile yapılan görüşmenin sonunda yer alan bu ifadelerde, Suriyelilerin harcayacakları emeklerin görev ve sorumlulukların adresi olarak Suriye toprakları gösterilmektedir.

“Kendi ülkelerine dönmelerini isteriz.” (E1 54 yaş).

“Kendi ülkelerine dönmeleri hoşumuza gider.” (K1 48 yaş)

Mekan, ileride Suriyelilerle ortak bir sahiplik içinde paylaşıma açık değildir. Sunulan öneri Suriyelilerin kendi iç grup dinamikleri içinde Suriye’de olmasına yöneliktir. Katılımcı çift (E1, K1), "kendi ülkelerine” ifadeleriyle ülkeler düzeyinde sahip oldukları KPS algısı üzerinden tepkilerini göstermiştir.

“...zor bir hayat ama Müslüman bir ülkede oldukları için şanslılar ordaki kalanlar için üzülüyorum inşallah Rabbim geri dönsünler yani evsizlik yurtsuzluk kötü bir şey vatansızlık kötü bir şey Rabbim onları tekrar vatanlarına kavuştursun inşallah dua ediyoruz yani” (K2, 56 yaş)

Katılımcılar Suriyelilerin yaşadıkları zorlukların temel sebebini 'yuva', 'vatan', 'yurt' gibi kolektif sahiplik alanlarına sahip olmamaları olarak görmektedir. Suriyelilerin ülkelerine geri dönmeleri, bu kolektif alanlara tekrar sahip olmaları için gereklidir. Temenni Suriyelilerin geri dönmesi yönündedir. 
Görüşmelerde ortaklaşan çözüm önerilerinin Suriyelilerin Türkiye'den gitmesi yönündeki temenni söylemleri üzerinden kurulduğu gözlemlenmiş fakat bu temennilerde Suriyeli göçmeni, kolektif sahipliğe davet eden söylemlerin yer aldığı herhangi bir çözüm önerisine rastlanmamıştır.

\section{TARTIŞMA}

Çalışmada, Suriyelilerin Türkiye'de gündelik hayat pratikleri, kamusal alanda görünürlükleri, şehirde varoluş şekillerine karşı yerel halkın tepkilerinin kolektif psikolojik sahiplik algısı içinde nasıl görünür hale geldiğine yönelik bulgulara yer verilmiştir. İlk temada, katılımcıların kolektif psikolojik sahiplik inşaları, ikinci temada Suriyelilerin kolektif psikolojik sahipliğin dışında tutulması, üçüncü temada kolektif kontrol kaybı endişesinin dişavurumu ve son temada ise Suriyeli göçü meselesine dair katılımcıların çözüm önerilerinin içeriği KPS kuramı üzerinden ele alınmıştır.

İlk temada, Suriyelilerin şehirde birer komşu ve kamu hizmetlerinin kullanıcısı olarak var oluşları, katılımcıların kolektif sahiplik inşalarında yeni bir dinamik oluşturmaktadır. Verkuyten ve Martinovic'in (2017) araştırmalarında işaret ettiği “öncelik” iddiası bir meşrulaştırma aracı olarak kullanılması gibi bu çalışmada da katılımcıların kolektif psikolojik sahiplik inşasında, bireysel tarihsellikleriyle bölgede önceden de yaşıyor olmanın önemli bir meşrulaştırma aracı olduğu gözlemlenmiştir. Öncelik iddiasıyla sınırlı kalmayıp alanda emek harcayan olma iddiasıyla da güçlendiriliyor olması Brown ve arkadaşlarının (2005) vurguladığı sahipliğin elde tutulması için mücadelenin devam ettiğini göstermektedir. Bununla beraber inşa sürecinde Suriyeliler ile yerel halk arasında yardım eden ve yardım edilen şeklinde kimlik odaklı işaretlemeler ortaya çıkmaktadır. Kolektif sahiplik psikolojisi katılımcıların ahlaki olarak nasıl konum alacaklarında da belirleyici olmuştur. Buradaki yardım olgusu, insani boyutta savaş sonrası travmatik duruma yardım müdahalesidir. Ahlaki bir sorumluluk olarak işaretlenen yardım etme eylemi, katılımcılar için kolektif sahipler olarak ulusal bağlamdan çıkarılarak, uluslararası aktörlerin sorumluluğuna yönlendirilmiştir. Bandura'nın (2002) ahlaki bağlantısızlık kuramında iddia ettiği gibi yardım eyleminin ahlaki bağlantısı, sorumluluğun dağıtılması boyutu üzerinden zayıflatılmıştır. Sorumluluğun uluslararası aktörlere dağıtılmasıyla yerli halkın kolektif olarak sahiplik alanlarına Suriyelilerin erişimine kısıtlama getirilmektedir. Yardımın içeriği incelendiğinde, Suriyelinin kolektif psikolojik sahipliğe dahil edilmesinin ve ulusal kaynakların paylaşımına, üretimine, emeğe beraber dahil olma 
gibi hak temelli katkıya dayalı yardım seçeneklerinin söz konusu edilmediği görülmektedir.

İkinci tema Suriyelilerin kolektif psikolojik sahipliğin dışında tutulmasının meşrulaştırılmasıdır. Yerel halkta, Suriyelilerin Türkiye'de varlık göstermelerini, sosyal hak ve hizmetlerin faydalanıcıları olmalarını ve KPS' de yer almalarını sağlayacak bir seçeneğe dair düşünce bulunmamaktadır. Kolektif sahiplik iddiasında kuramsal bağlamda etkili olan emek ve yatırım şartı ilkesinin araştırma verilerinde yerel halk tarafından sıklıkla vurgulandığg gözlemlenmiştir. Bu bulgular, Suriyelilerin ekonomik yük ve iş rekabetine neden olduğuna dair verilere sahip çalışmalarla (Erdoğan, 2018; Güney ve Konak, 2016; Polat ve Eda, 2017) örtüşüyor görünebilir fakat yerel halkın gözünde Türkiye için emek harcama ve faydalı olma gibi sahipliğe ortaklık şartları Suriyeliler tarafından karşılanabilecek şartlar değildir. Çünkü Suriyeliler aynı zamanda 'savaştan kaçan', 'hamuru farklı olanlar' şeklinde içsel atıflar yapılarak işaretlenmektedir. Mevcut çalışma bize bu tür içsel atıfların, Suriyeli göçmenin Türkiye'deki hayatında kolektif sahipliğe dahil olmak için harcayacağı emeğin ya da göstereceği faydanın yetersiz bir girişim olarak algılanmasına veya görmezden gelinmesine neden olabileceğini düşündürmektedir. $\mathrm{Bu}$ düşünce, gruplar arası gerilimin nedenlerini Suriyelilerin ekonomik yük veya rekabet faktörü olarak düşünülmesi şeklinde getirilen açıklamalara KPS kura$\mathrm{m}$ alternatif bir yaklaşım sunabilmektedir.

Yerel halk kolektif sahiplik iddiası içinde olduğunda kendilerini Suriyelilerle ya da yerli halktan başka biriyle kıyaslama girişimlerinde bulundukları gözlemlenmiştir. Katılımcılar için Suriyelilere kıyasla kendilerinin hem bireysel hem de kolektif tarihi kimlikler açısından bu topraklara daha önce gelmiş olma durumu 'memleket için harcanan emek' karşılaştırmasında yerel halk için avantajlı bir kıyaslama aracı olarak kullanılmıştır. Suriyeli göçmenler KPS'nin yatırım ilkesine sahip olsalar dahi, yerel halk tarafından kolektif sahipliğe dahil edilmemektedir. Yerel halkın sunduğu çözümde yatırım ilkesiyle örtüşen çözümler bulunmaktadır. Fakat bu çözümde katılımcılara göre yatırımın yapılması gereken adres bellidir. Suriyeliler, kendi tarihi kimliklerinden gelen kolektif sahiplik alanlarında (örneğin Suriye'de kendi topraklarında) yatırım yapmalıdır. Vignoles'in (2011) vurguladığ1 kolektif sahiplik alanlarının müzakeresi edildiğinde Suriyeli göçmenler için dezavantajlı olduğu durumlar her zaman masada olacaktır. Araştırmanın bulguları 1şığında Levene ve arkadaşlarının (2015) kolektif sahiplik kuramına yatırım ilkesi üzerinden katkısına şu ekleme yapılabilir: Kolektif sahiplik alanına dış grup üyesi 
yatırım ilkesi üzerinden kabul edilmeyip, aksine dış sahiplik alanlarına yatırım ilkesi aracılığıyla yönlendirilmektedir. Diğer bir ifadeyle, yatırım ilkesinin, KPS'nin bir aracı olmak yerine kolektif dışlanmanın bir meşrulaştırma aracına dönüştüğü görülmektedir.

Üçüncü tema kolektif kontrolün kaybı endişesi altında yer alan bulgulardan oluşmaktadır. Suriyeli göçmenlerin Türkiye'ye geçişlerinin hızlı ve kitlesel oluşu katılımcılar için kontrolsüz olarak algılanmıştır. KPS kuramının temel iddialarından birini oluşturan mülk ve mekan üzerinde sahiplerin kontrol hakkı olduğuna dair inancın sarsılmasıyla oluşan endişenin (Verkuyten ve Martinovic, 2017), Suriyeli göçmenlere yönelik olumsuz algının oluşmasına neden olduğu iddia edilebilir. Üçüncü tema altındaki ifadelerde yer alan Suriyelinin Türkiye'de varoluşlarının 'salınarak', 'kontrolsüz gelen've 'rahatı yerinde' söylemleriyle ifade ediliyor olmasının nedeni, teoride geçen kullanıcı ve sahip olma ayrımının yerel halk için muğlak olmaya başlamasıyla açıklanabilir. Yardım edilen, yardıma muhtaç ve izin verildiği kadarıyla sadece kontrol altındaki kullanıcı olarak işaretlenen Suriyeli, sahiplik iddiasında bulunan şeklinde işaretlenmeye başlamıştır. Bu durum, dış grup üyesi olan Suriyeliye karşı tepki gösterme sebebi olarak yorumlanabilir. Suriyeliye karşı konum alma, yerel halkın iç grup özdeşim düzeylerini daha da yükseltebilmektedir. Bu durumda bireyler, üyesi oldukları grubun prototip davranışlarını daha fazla performe edebilmekte, yani benlik kategorizasyonu eğilimine daha fazla sahip olabilmektedir (Turner ve ark., 1987). Bu kuramsal bilgi mekanın kolektif olarak sahiplenilmesi üzerinden tekrar düşünüldüğünde, 'aynı mahalleli', 'yerliler' olarak ifade edilen yerel halk sahip oldukları yerel kimlik kategorizasyonu içinde mahallede yeni olan gündelik yaşam ve varoluş şekilleriyle etkileşimin diğer tarafında olan Suriyeliye tepki göstermenin meşrulaşmasına neden olabilmektedir. Bu aynı zamanda daha makro düzeyde kolektif tavır alma şekillerini açıklarken de dikkate alınabilir. Göçmenlerin Suriye sınırındaki kamplarda savaş süresince tutulmaları konusunda politik önerilerin katılımcılar tarafından destekleniyor olması alan yazında geçen kontrol odaklı işaretlemelere örnek gösterilebilir.

Temenni düzeyinde çözüm önerilerinin meşrulaştırılması başlıklı son temada, Suriye'deki çatışmaların sona ermesinin ardından göçmenlerin ülkelerine geri dönmeleri yönünde yerel halkın taleplerinin olması KPS alanının paylaşıma açık olmadığını göstermektedir. Katılımcıların Suriyeli göçmenlerle kurduğu empatinin içerikleri KPS alg1S1 çerçevesinde düşünülebilir. Suriyeli göçmenler ülkesinde sahip olduklarına artık sahip değildir. Katılımcı bu noktada, kendi sahip olduklarının olası kaybı üzerinden Su- 
riyeli göçmenle empati kurmaktadır. Dolayısıyla KPS kaybına karşı duyulan endişe üzerinden Suriyeli göçmen için temenni ettiği şey bir bakıma kendisi için de bir temenniye dönüşebilmektedir. Bu temenni KPS alanlarını kaybetmeme isteğidir.

Çalışmanın bulguları, KPS mekanizmalarının hangi durumlarda ve nasıl oluştuğuna dair geniş bir bakış açısı sunmaktadır. Bunun sebeplerinden biri bulguların, yerel halk tarafından Suriyelilerin Türkiye'de tehdit olarak algılanmasının altındaki nedenin sadece ekonomik yük olarak algılanıyor olduklarını değil; Türkiye'de sunulan sosyal imkan ve hizmetlerin kullanıcısı, ekonomik faaliyetleri (mülk edinme, iş kurma, çalışma, yatırım yapma) gerçekleştiriyor olmaları, yani yeni sahipler olarak algılanmalarından kaynaklanan bir rahatsızlık halinin olduğunu gösteriyor olmasıdır. Çalışmadan elde edilen bu çıkarım, Nijs, Verkuyten ve Martinovic'in (2021) deneysel çalışmasıyla oldukça paralellik göstermektedir. Çalışmada Hollandalılar, Türkiye'nin Avrupa Birliğine dahil olmasının Hollanda için ekonomik veya sembolik bir tehdit yerine ülke üzerindeki kolektif sahipliklerinin ihlaline yönelik bir tehdit olarak görmüşlerdir. Suriyeliler'e yönelik kamuoyundaki tepkiler de bu çıkarım üzerinden incelenebilir. Sosyal medyada 2021 y1l ekim ayında paylaşılan "ben muz yiyemiyorum siz Suriyeliler kilolarca muz alıyorsunuz" yerel halk söylemlerine Suriyelilerin muz yerken çekilmiş görüntülerle eleştirel yaklaşımı kamuoyunda ses getirmiştir. Sosyal medya üzerinden Suriyelilere yönelik tepkilerin artması sonrası T.C İç İşleri Bakanlığı Göç İdaresi Genel Müdürlüğü (2021) tarafından kamuoyuna görüntülerde yer alan Suriyeliler hakkında soruşturma başlatıldığı ve sınır dışı edileceği açıklaması yapılmıştır. Suriyeliler bugüne kadar kolektif olarak sahip olunanların artık yeni ortakları olarak algılanmaktadır. Diğer bir sebebi ise bulguların yerel halkın Suriyelilerle bireysel deneyimleri dışında grup dinamikleri üzerinden incelenebilecek birçok bilgiyi barındırıyor olmasıdır.

Çalışmanın sınırlılıkları ise şu şekilde ele alınabilir: Görüş̧me verileri elde edildiği 2019 yılında Türkiye yerel seçimleri sonrası Suriyelilerin kontrol altında tutulması ve sınır dışı edilmeleri gibi göçmenlere yönelik politik tavırdaki değişimin daha net gözlemlendiği politik uygulamalar ortaya çıkmıştır. Araştırmanın yapıldığı dönem sonrası gündemde olan Suriye'nin kuzeyi ve Türkiye sınırı arasında planlanan $30 \mathrm{~km}$ genişliğinde güvenli bölge oluşturma planları, katılımcılar tarafından ortaya konulan çözüm önerilerinin politik yansıması olarak değerlendirilebilir. Bu yeni gelişmeler ışığında Türkiye'deki Suriyeli göçmenlere yönelik çözüm önerileri üzerine yapılacak yeni çalı̧smalar, bu çalışmayı tamamlayıcı nitelikte olacaktır. Benzer şekilde başkja bir yeni olgu 
olan pandemi sürecinde Covid-19 aşılarına erişim sorunları da KPS olgusu üzerinden incelenebilir. Ülkelerin belli ekonomik maliyetlerle sahip oldukları aşıları yine kendi ülkelerinde yaşayan göçmenlerin de erişimine sunmaları halinde yaşanabilecek olası tartışmalar KPS kuramı üzerinden ele alınabilir. Türkiye'de farklı göçmen grupları bağlamında KPS kuramı üzerinden yapılacak yeni çalışmaların sonuçları bu çalışma ile karşılaştırılabilir. Bu çalışmada, katılımcıların yerel halk içinden İstanbul'da en az 10 yıldır yerleşik şekilde yaşayan, sosyo-demografik özellikleri, değerleri birbirine yakın Türkiye Cumhuriyeti vatandaşı evli ve çocuklu olması kriterleri üzerinden araştırma evreninin sınırları belirlenmeye çalışılmıştır. Bu evrenin dışında kalan farklı değerlere ve sosyo-demografik özelliklere sahip örneklemler ile yapılacak bir çalışmanın bulguları buradaki sonuçlara yeni katkılar sağlayacaktır. Bu çalışmadan elde edilen bulguların 10 evli çiftin görüşme analizleri ile sınırlı tutulması çalışmanın diğer bir sınırlılığıdır. Niteliksel çalışmanın sonuçlarının bağlamsal ve örneklem özelinde değerlendirilmesi gerekliliği önemlidir. Fakat yine de örneklem büyüklüğü arttırılarak çalışmanın tekrarlanması veya farklı illerde yapılacak çalışmaların mevcut çalışma ile karşılaştırılması çalışmanın bulgularına destek sağlayacaktır.

Sonuç olarak, bu çalışma, Türkiye'de Suriyeliler ile yerel halk arasındaki ilişkileri bizim-onların sahip oldukları bağlamında inceleyerek gruplararası çatışmaların içeriğini anlamaya yönelik bir adımdır. Çalışmanın temel iddialarından biri, Suriyeli göçmene karşı yerel halkın sürekli savunduğu ve göçmeni dışarıda tuttuğu bir KPS alanına sahip olduğu yönündedir. Suriyeliler, Türkiye'de sunulan sosyal imkan ve firsatlara erişebilme, kolektif alanda var olma adına gerekli şartlara sahip olsa bile bu duruma yönelik başka bir savunma alanı kendini yeniden kurmakta ve göçmen bu kolektif sahiplik alanı dışında kalmaya devam etmektedir. Örneğin, ülkeye veya şehre yatırım yapabilecek bir Suriyeli diğer taraftan kültürel ve tarihi sosyal kimliğe sahip olmadığı için KPS alanı dışında tutulmaya devam etmektedir. Buna ek olarak çalışmanın alan yazına en önemli katkısı, KPS kuramı üzerinden Suriye göçünün ele alınmasının, göçmenin dili, dini ve kimlik özellikleri ne olursa olsun yerel halk ile temel hukuki ve insani güvenceleri eşit derecede hak ediyor olmasını savunan ahlaki konum alış ile belli grup üyelerine önceliği, kontrol ve kullanım hakkını temel alan kolektif psikolojik algısı arasındaki gerilimi ortaya koymuş olmasıdır. 
Hakem Değerlendirmesi: Dış bağımsız.

Çıkar Çatışması: Yazar çıkar çatışması bildirmemiştir.

Finansal Destek: Yazar bu çalışma için finansal destek almadığını beyan etmiştir.

Peer-review: Externally peer-reviewed.

Conflict of Interest: The author has no conflict of interest to declare.

Grant Support: The author declared that this study has received no financial support.

\section{Kaynakça/References}

Akfırat, S. ve Yangın, E. (2018). Ev sahibi topluluk kültürleşme ölçeği (ETKÖ) Türkçe for m un un psikometrik özelliklerinin üniversite öğrencileri örnekleminde incelenmesi. Sosyal Bilimler Dergisi (29), 499-519.

Alkaya, B. ve Korkmaz, D. T. (2018). Dokunma ihtiyacı ve yazılı bilginin psikolojik sahiplik üzerindeki etkisi. Pazarlama ve Pazarlama Araştırmaları Dergisi 11(22), 205-232.

Avrupa Siyasal ve Sosyal Araştırmalar Enstitüsü. (2017). Bilgiden algıya: Türkiye'deki sı̆̆ınmacı, göçmen ve mülteci algısı üzerine bir çalı̧̧ma. Viyana: PS:EUROPE. 6.16. 2020 tarihinde. Erişim adresi: http://ps-europe.org/tr/

Azak, Y. ve Yurtdaş, G. T. (2021). Mekânla belirlenen yaşamlar: Güvenlikli konutlarda yaşamak. Elektronik Sosyal Bilimler Dergisi, 20(77), 340-355. doi:10.17755/esosder.625950

Bandura, A. (2002). Selective moral disengagement in the exercise of moral agency. Journal of Moral Education, 31(2), 101-119. doi:10.1080/0305724022014322

Braun, V. ve Clarke, V. (2006). Using thematic analysis in psychology. Qualitative Research in Psychology, 3(2), 77-101. https://doi.org/10.1191/1478088706qp063oa

Brown, G., Lawrence, T., ve Robinson, S. L. (2005). Territoriality in organizations. Academy and Management 30(3), 577-595.

Clarke, V ve Braun, V. (2013) Teaching thematic analysis: Overcoming challenges and developing strategies for effective learning. The Psychologist, 26(2).120-123.

Erdoğan, M. (2018). Suriyeliler barometresi: Suriyelilerle uyum içinde yaşamanın çercevesi. İstanbul: İstanbul Bilgi Üniversitesi Yayınları. Erişim adresi:https://www.mmuraterdogan.com/raporlar

Erdoğan, M. (2019) Syrian refugees in Turkey. Araştırma raporu, İstanbul. Erişim adresi: https://www. kas.de/de/web/tuerkei/home

Erdoğan, M. ve Çorabatır, M. (2019). Suriyeli mültecilerin demoğrafik gelişimi, Türkiyedeki eğitim istihdam ve belediye hizmetlerine yakın gelecekte olası etkileri. Araştırma raporu, İstanbul. Erişim adresi: https://www.mmuraterdogan.com/

Erişen, C. (2018). Causes and consequences of public attitudes toward Syrian refugees in Turkey. Contemporary Research in Economics and Social Sciences, 2(1),111-139.

Friedman, O. (2008). First possession: An assumption guiding inferences about who owns what. Psychonomic Bulletin 15(2), 290-295.

Friedman, O. ve Neary, R. (2008). Determining who owns what: Do children infer ownership from first possession? Cognition. 107(3),829-849. doi: 10.1016/ 2007.12.002.

Guest, G, Bunce, A. ve Johnson, L. (2006). 'How many interviews are enough? An experiment with data saturation and variability', Field Methods, 18, 59-82.

Güney, Ü. ve Konak, N. (2016). Bolu'da Suriyeli ve Iraklı sığınmacılar: Vatandaşlık ve kaynak dağılımı temelinde öteki alg1s1. Siyasal Bilimler Dergisi, 4(2), 113-135. 
International Organization for Migration (IOM). (2019). Migrants' presence monitoring in Istanbul, baseline assessment round II I. Gözlem Raporu, IOM, Newyork. Erişim ａdresi: ～https:// displacement.iom.int/system/tdf/reports/IST_Baseline_Assessment_Phase 5_EN

İçduygu, A. (2015). Syrian refugees in Turkey the long road ahead. İstanbul: Migration Policy InstituteKirişçi, K. ve Ferris, E. (2014). Syrian refugees and Turkey's challenge: Going beyond hospitality. Washington: Brooking.

Levene, M., Starmans, C. ve Friedman, O. (2015). Creation in judgments about the establishment of ownership, Journal of Experimental Social Psychology, 60, 103-109.

Levitt, H. M., Bamberg, M., Creswell, J. W., Frost, D. M., Josselson, R. ve Suárez-Orozco, C. (2018). Journal article reporting standards for qualitative primary, qualitative meta-analytic, and mixed methods research in psychology: The APA publications and communications board task force report. American Psychologist, 73(1),26-46. doi: 10.1037/amp0000151

Maguire, M. ve Delahunt, B. (2017). Doing a thematic analysis: A practical, step-by-step guide for learning and teaching scholars. AISHE-J (3), 3351-3365.

Martinovic, B. ve Verkuyten, M. (2013). 'We were here first, so we determine the rules of the game': Autochthony and prejudice towards out-groups. European Journal of Social Psychology, 43(7), 637-647. doi: 10.1002/ejsp.1980

Mülteciler Derneği. (2021, Kasım 25). Türkiye'deki Suriyeli sayısı, Aralık,14, 2021 tarihinde. Erişim adresi: https://multeciler.org.tr/turkiyedeki-suriyeli-sayisi/ adresinden alındı

Nijs T., Verkuyten M. ve Martinovic B. (2021). Losing what is ours: The intergrup consequences of collective ownership threat. Group Process \& Intergroup Relations. 00(0), 1-19. doi: $10.1177 / 1368430220980809$

Ötken, A. B. (2015). Algılanan örgütsel destek ve psikolojik sahiplenme arasındaki ilişki ve bu ilişkide örgütsel adaletin rolü. Hacettepe Üniversitesi İktisadi ve İdari Bilimler Fakültesi Dergisi,33(2),113-140. doi: 10.17065/huiibf.83618

Pierce, J. L., Kostova, T. ve Dirks, K. T. (2001). Toward a theory of psychological ownership in organizations. Academy of Management Review,26(2),298-310. doi: 10.5465/AMR.2001.4378028

Polat, F. Ç. ve Eda, K. (2017). Bir ötekileştirme pratiği: Türkiye'de yaşayan Suriyelilere yönelik tutumlar. Mersin Üniversitesi Sosyal Bilimler Enstitüsü Dergisi, 1(1), 38-48.

Robinson O. C. (2014) Sampling in interview-based qualitative research: A theoretical and practical guide, Qualitative Research in Psychology, 11:1, 25-41. doi: 10.1080/14780887.2013.801543

Sarı, A. Ç. ve Alkar, Ö. Y. (2018). The attitudes towards Syrians living in Turkey: A scale development. The Journal of Migration Studies, 4(2), 10-36.

Smeekes, A., Verkuyten, M., Çelebi, E., Acartürk, C. ve Onkun, S. (2017). Social identity continuity and mental health among Syrian refugees in Turkey. Social Psychiatry and Psychiatric Epidemiology, 52, 1317-1324. https://doi.org/10.1007/s00127-017-1424-7

Şar E. ve Kuru N O. (2020). İstanbul'da Suriyeli sığınmacılara yönelik tutumlar. Araştırma Raporu 11, İstanbul: İstanpol Politik Araştırmalar Enstitüsü (ISTANPOL).

T.C. İç İşleri Bakanlığı Göç İdaresi Genel Müdürlüğü (GİGM). (2021). Yıllara göre gecici koruma kapsamındaki Suriyeliler. Ankara: GİGM. Erişim adresi: https://www.goc.gov.tr/gecici-koruma5638

T.C. İç İşleri Bakanlığı Göç İdaresi Genel Müdürlüğü (GİGM). (2021, Kasım 27). Sosyal medyada dolaşıma sokulan provokatif paylaşımlar hakkında. Ankara: GİGM. Kasım 23, 2021 tarihinde. Erişim adresi: https://www.goc.gov.tr/sosyal-medyada-dolasima-sokulan-provokatif-paylasimlarhakkinda

Temizkan, Ö. Y. (2019). Psikolojik güçlendirme ile psikolojik sahiplenme arasındaki ilişkinin 
değerlendirilmesi: Devlet hastanesi örneği. Ankara Hacı Bayram Veli Üniversitesi İktisadi ve İdari Bilimler Fakültesi Dergisi, 3(21), 640-665.

Tobin, G. A. ve Begley, C. M. (2004). Methodological rigour within a qualitative framework. Journal of Advanced Nursing, 48(4), 388-396. doi:10.1111/j.1365-2648.2004. 03207.x

Tetlock, P. E., Kristel, O., Elson, B., Green, M. ve Lerner, J. S. (2000). The psychology of the unthinkable. Taboo tradeoffs, forbidden base rates, and heretical counterfactuals. Journal of Personality and Social Psychology, 78,853-870.

Turner, J. C., Hogg, M. A., Oakes, P. J., Reicher, S. D. ve Wetherell, M. S. (1987). Rediscovering the social group: A self-categorization theory. Oxford: Blackwell.

Uçar, Z. (2020). Psikolojik sahiplik olgusunu örgütsel düzlemde ölçmek için ölçek geliştirme çalışması. Journal of Business Research-Turk, 10(3) 640-654. doi:10.20491/isarder.2018.492

Verkuyten, M. (2018). The benefits of studying immigration for social psychology. European Journal of Social Psychology, 93, 225-239.

Verkuyten, M. ve Martinovic, B. (2017). Collective psychological ownership and intergroup relations. Perspectives on Psychological Science, 12(6), 1021-1039. doi:10.1177/1745691617706514

Verkuyten, M., Sierksma, J. ve Thijs, J. (2014). First arrival and owning the land: How children reason about ownership of territory. Journal of Environmental Psychology, 41, 58-64.

Vignoles, V. L. (2011). Identity motives. K. Luycke, S. J. Schwartz ve V. L. Vignoles (Ed.) Handbook of identity theory and research içinde (s. 403-432). New York: NY: Springer.

Walters, W. (2004). Secure borders, safe haven, and domopolitics. Citizenship Studies, 8, 237-260.

Yeşil, Ü., Bancar, A. ve Budak, G. (2016). Psikolojik sahiplik kavramına ilişkin bir literatür incelemesi. Eskişehir Osmangazi Üniversitesi Sosyal Bilimler Dergisi, 16(2), 59-82. doi:10.17494/ ogusbd.57630.

Zebian, S. ve Rochat, P. (2012). Judgment of land ownership by young refugee Palestinian and U.S. children. International Journal of Behavioral Development, 36, 449-456. 


\section{Ek1: Görüşme Soruları}

1. Kendinizden, aile yaşantınızdan bize biraz bahseder misiniz?

2. Dini yaşamınız, dini inancınız, hatta politik görüşünüz hakkında neler söylemek istersiniz?

3. Varsa ailenizin geçmişinde ya da aile büyüklerinizin geçmişindeki göç deneyimlerini anlatabilir misiniz?

4. Türkiye'de Suriyeliler ve göç hakkında ne düşünüyorsunuz?

5. Göç meselesine nasıl bakıyorsunuz?

a) Neleri sorun olarak görüyorsunuz?

b) Sorunun kaynağı sizce ne olabilir?

c) Göçmenlerin ne gibi talepleri olabilir?

d) Vatandaşl1k verilip verilmemesi konusunda neler düşünüyorsunuz?

d) Bu taleplerin hangisini karşılayabilir, hangilerini karşılayamayız?

e) Sorunları çözebilme adına neler yapılabilir? Çözüm önerileriniz nelerdir? 
